\title{
Wind-driven estuarine turbidity maxima in Mandovi Estuary, central west coast of India
}

\author{
Pratima M Kessarkar, V Purnachandra RaO*, R Shynu, Ishfaq Mir Ahmad, \\ Prakash Mehra, G S Michael and D Sundar \\ National Institute of Oceanography, Dona Paula 403 004, Goa, India. \\ *e-mail:vprao@nio.org
}

\begin{abstract}
Systematic studies on the suspended particulate matter (SPM) measured on a seasonal cycle in the Mandovi Estuary, Goa indicate that the average concentrations of SPM at the regular station are $\sim 20 \mathrm{mg} / \mathrm{l}, 5 \mathrm{mg} / \mathrm{l}, 19 \mathrm{mg} / \mathrm{l}$ and $5 \mathrm{mg} / \mathrm{l}$ for June-September, October-January, February-April and May, respectively. SPM exhibits low-to-moderate correlation with rainfall indicating that SPM is also influenced by other processes. Transect stations reveal that the SPM at sea-end stations of the estuary are at least two orders of magnitude greater than those at the river-end during the monsoon. Estuarine turbidity maximum (ETM) of nearly similar magnitude occurs at the same location in two periods, interrupted by a period with very low SPM concentrations. The ETM occurring in June-September is associated with low salinities; its formation is attributed to the interactions between strong southwesterly winds $\left(5.1-5.6 \mathrm{~ms}^{-1}\right)$ and wind-induced waves and tidal currents and, dominant easterly river flow at the mouth of the estuary. The ETM occurring in February-April is associated with high salinity and is conspicuous. The strong NW and SW winds $\left(3.2-3.7 \mathrm{~ms}^{-1}\right)$ and wind-driven waves and currents seem to have acted effectively at the mouth of the estuary in developing turbidity maximum. The impact of sea breeze appears nearly same as that of trade winds and cannot be underestimated in sediment resuspension and deposition.
\end{abstract}

\section{Introduction}

Estuaries are dynamic environments characterized by strong seasonal changes in salinity, $\mathrm{pH}$, suspended particulate matter $(\mathrm{SPM}), \mathrm{O}_{2}$ concentration and current velocities (Kennedy 1984). Suspended matter is of primary importance for aquatic health and environmental management and, constitutes a key parameter in the estuary. The concentrations of SPM in the estuary are controlled by

- riverine input,

- mixing of riverine suspended matter and particles of marine origin,

- resuspension of sediments,

- flocculation and coagulation of colloidal material
- production of organic matter by phyto- and zooplankton, and

- industrial and domestic waste and associated phenomenon (absorption, adsorption and desorption).

An often reported phenomenon is the 'estuary turbidity maximum' (ETM) where much higher concentrations of suspended sediment occur in the estuary than in either the river or the sea (Schubel and Kennedy 1984; Dyer 1986). Freshwater flow into an estuary affects the salinity field and, therefore, can affect the position of ETM. ETM is usually located near the upstream limits of salt intrusion and at low salinities. However, they can also be located at much greater salinities; for example the ETM in Lorient and Vilaine bays are at

Keywords. Suspended particulate matter; monsoons; turbidity maximum; winds; estuarine sedimentation. 
salinities of about $18 \%$ and $25-30 \%$, respectively (Le Bris and Glemarec 1996). The formation of ETM is often attributed either to (a) gravitational circulation or (b) tidal asymmetry; the former is more important in partially mixed estuaries with microtides and mesotides (Schubel 1968), while the latter in macrotidal estuaries (Allen et al 1980; Kirby and Parker 1983). A cycle of local deposition, bed erosion and resuspension also can contribute to the development of ETM (Uncles et al 1994; Wolanski et al 1995). Schoellhamer (2001) reported the influence of salinity, bottom topography and tides on locations of ETM on northern San Francisco Bay. Chen et al (2005) reported the existence of three ETM in different parts of the Scheldt Estuary and processes for their formation. On the other hand, several others noted the suppression of turbulence by salinity stratification and demonstrated that this process exists in the landward end of the salt intrusion and act as an effective trapping mechanism for fine sediment (Hamblin 1989; Geyer 1993).

Tropical estuaries of the west coast of India experience seasonal changes in climate and physical oceanographic processes. During the southwest (SW) monsoon (June-September) maximum rainfall occurs and rivers carry abundant fine-grained material into the estuaries and coastal regions. The dominant river flow is counteracted by the strong westerly winds, wind-induced waves and currents and tides. On the other hand, rainfall is negligible between October and May and therefore terrigenous sediment discharge is the least. Weak easterly winds prevail during the northeast (NE) monsoon (November-February). The flow in the estuary, however, is tidal-dominated and saline waters occur several kilometers upstream from the river mouth (Shetye et al 1995). The industrial and mining activities at several points along the estuary are at peak during October-May and contribute some suspended matter. The daily to-and-fro traffic of numerous mechanized fishing boats and barges carrying Fe-Mn ores may induce some turbidity to the estuarine system. Turbidity plays an important role in maintaining 'health of the estuary'. If turbidity exceeds $1 \mathrm{~g} / \mathrm{l}$, oxygen concentrations deplete and correspond to hypoxic conditions and may have deleterious effects on macrofauna. Nutrients, heavy metals and other pollutants can be trapped in the turbidity zone wherein high concentrations of bacterial populations were reported. Another important aspect of ETM is that it may acts as 'nursery area' for some fish eggs and larvae to spend time. Eggs are masked from predators under the cover of high turbidity (North et al 2005). Systematic time-series studies suitable for identifying seasonal effects on SPM and ETM, in particular, are lacking and better understanding on the processes controlling them are necessary. The aim of the paper is to report for the first time systematic studies on the characteristics of SPM and ETM in the Mandovi Estuary, Goa, India on a seasonal cycle and identify the processes that control them.

\subsection{Study area and background data}

The Mandovi and Zuari rivers in the state of Goa with its interconnecting canal (figure 1) in the central west coast of India form an important estuarine system. It is classified as coastal plain estuary. The Mandovi River is $\sim 75 \mathrm{~km}$ long with a drainage basin of $\sim 1895 \mathrm{~km}^{2}$ (Qasim and Sengupta 1981). The width of the river at the mouth (in the bay) is $\sim 4 \mathrm{~km}$ and the average depth is $5 \mathrm{~m}$. The width of the main channel at its mouth is $3.2 \mathrm{~km}$ and gets progressively narrower (to $0.25 \mathrm{~km}$ ) and shallower upstream. The annual rainfall along the course of the river varies considerably from $661 \mathrm{~cm}$ at Gavali (upstream of the river in the Western Ghats) to $413 \mathrm{~cm}$ at Valpoi and, to $286 \mathrm{~cm}$ at Panaji $(\sim 6 \mathrm{~km}$ from the mouth of the river) (Shetye et al 2007). Virtually all of the fresh water influx occurs only during the SW monsoon. The winds are stronger, westerly to southwesterly with a speed of $\sim 4-7 \mathrm{~ms}^{-1}$. Heavy spells and intensified wave activity and tides of $\sim 2-2.5 \mathrm{~m}$ height were reported (Shetye et al 1995; Sundar and Shetye 2005). The runoff of the river in the remaining eight months is almost negligible and the Mandovi Estuary simply becomes an extension of sea (Shetye et al 2007). The strength of the winds decreases and wind field is dominated by sea breeze (Neetu et al 2006). The flow in the estuarine channel is primarily tidal and continues to be so until the onset of next SW monsoon. The tides occur up to a distance of $50 \mathrm{~km}$ from the mouth. The Mandovi receives $\sim 5.21 \times 10^{6} \mathrm{~m}^{3}$ of sewage and their effluents per year (Qasim and Sengupta 1981). Currents were measured by mooring current meter. Currents of $\sim 31 \mathrm{~cm} / \mathrm{s}$ and $\sim 33 \mathrm{~cm} / \mathrm{s}$ occur at Reis Magos during April and September 2006, respectively. Similarly, currents of $\sim 43 \mathrm{~cm} / \mathrm{s}$ and $70 \mathrm{~cm} / \mathrm{s}$ occur at Cumburjua canal during August and December 2007, respectively (M T Babu, NIO, personal communication).

\section{Materials and methods}

Two types of data were collected in the Mandovi Estuary under the framework of 'Mandovi Monsoon Experiment 2007', conducted during June 2007-May 2008. (a) Salinity data and surface and sub-surface waters were collected every day at one station in the mid-channel of the Mandovi 


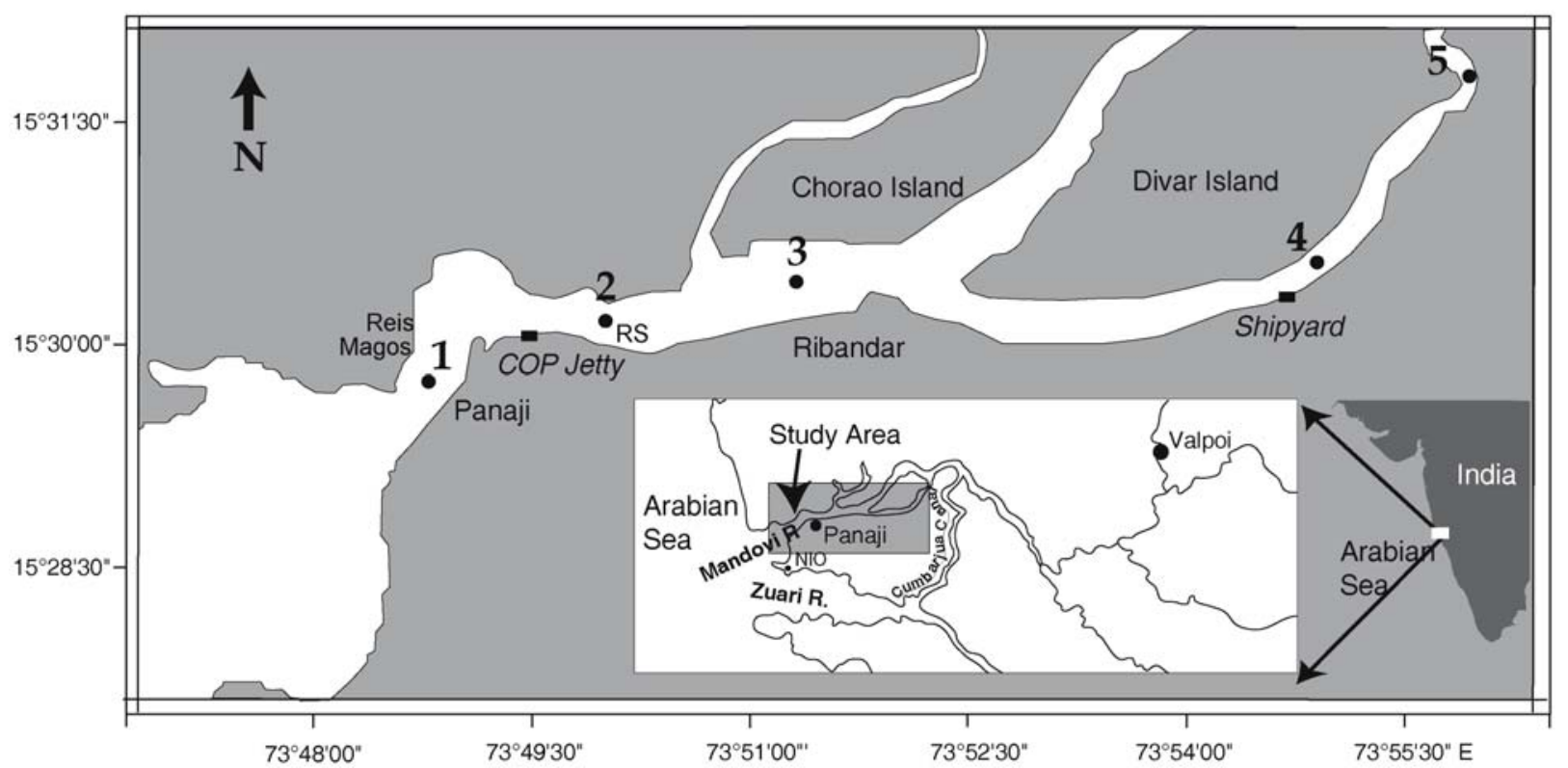

Figure 1. Location map of the Mandovi River and sampling stations in the river channel. RS - regular station. Numbers 1-5 are transect stations (TS) along the estuary. 1: Campal, 2: Secretariat, 3: Raibander, 4: Cumberjua and 5: Cumberjua canal.

Estuary from 24 May to 1 October, 2007. This station here is referred to as 'regular' station (RS), which is located $\sim 6.3 \mathrm{~km}$ away from the mouth of the Mandovi River (figure 1). Salinity data and SPM measured from surface water samples at every alternate day at RS were used for the present study. (b) Salinity data, surface water and bottom sediments were also collected fortnightly at five stations along the main channel of the Mandovi Estuary (hereafter referred to as 'transect' stations - TS), covering a distance of $\sim 19 \mathrm{~km}$ from the mouth of the river using a mechanized boat. Station 1 is at sea-end and station 5 at the riverend of the estuary (see figure 1 ). Station 2 is a regular station. Stations 1, 2, 3, 4 and 5 are at $\sim 5 \mathrm{~km}$, $6.3 \mathrm{~km}, 10.4 \mathrm{~km}, 16.3 \mathrm{~km}$ and $19.4 \mathrm{~km}$, respectively away from the mouth of the Mandovi River. This study focuses on the concentration of the suspended particulate material (SPM) at RS and TS. Five liters of surface water collected at each station were filtered on to $0.4 \mu \mathrm{m}$ Millipore filter paper. Three filter papers were used for each station and the SPM retained on filter papers was dried and weighted. SPM is expressed as $\mathrm{mg} / \mathrm{l}$. The National Institute of Oceanography (NIO) is located on the southern bank of the Mandovi Estuary and $\sim 6 \mathrm{~km}$ seaward of the regular station (see figure 1). Automatic weather station installed on the NIO building terrace transmits real time data on wind, air temperature, humidity and atmospheric pressure. The wind speed and direction collected for every 10 minutes was used for the present study.

\section{Results}

\subsection{Suspended particulate matter (SPM), rainfall and salinity}

\subsubsection{Regular station}

The concentrations of SPM, salinity of the surface waters and rainfall measured at two rain gauge stations (Valpoi and Panaji - see figure 1) are shown in figure 2. Several peaks of high SPM are recorded between June and September. A maximum SPM concentration of $158 \mathrm{mg} / \mathrm{l}$ for July 2007 and $129 \mathrm{mg} / \mathrm{l}$ for August 2007 was recorded. The surface waters do not retain high SPM for a long time. The peaks of high SPM values sharply fall to $\sim 20 \mathrm{mg} / \mathrm{l}$ or less within 48 hours (figure 2). The average concentration of SPM in May is $5 \mathrm{mg} / \mathrm{l}$ and increases to $\sim 20 \mathrm{mg} / \mathrm{l}$ for June-September 2007. Fortnightly observations at the RS from October 2007 to May 2008 indicate that the average concentrations of SPM are $5 \mathrm{mg} / 1,19 \mathrm{mg} / \mathrm{l}$ and $5 \mathrm{mg} / \mathrm{l}$ for October-January, February-April and May, respectively. The rainfall at Valpoi was much higher than that of Panaji. During active periods of rainfall peaks of high rainfall at Valpoi correspond well with that of Panaji. The active spells of high rainfall are in the range between 150 and $250 \mathrm{~mm} /$ day at Valpoi and, $150-200 \mathrm{~mm} /$ day at Panaji (figure 2). Comparison of plots of rainfall with SPM shows that SPM lags behind rainfall at the initial phase of the monsoon. The peaks of high SPM largely correspond well with that of 


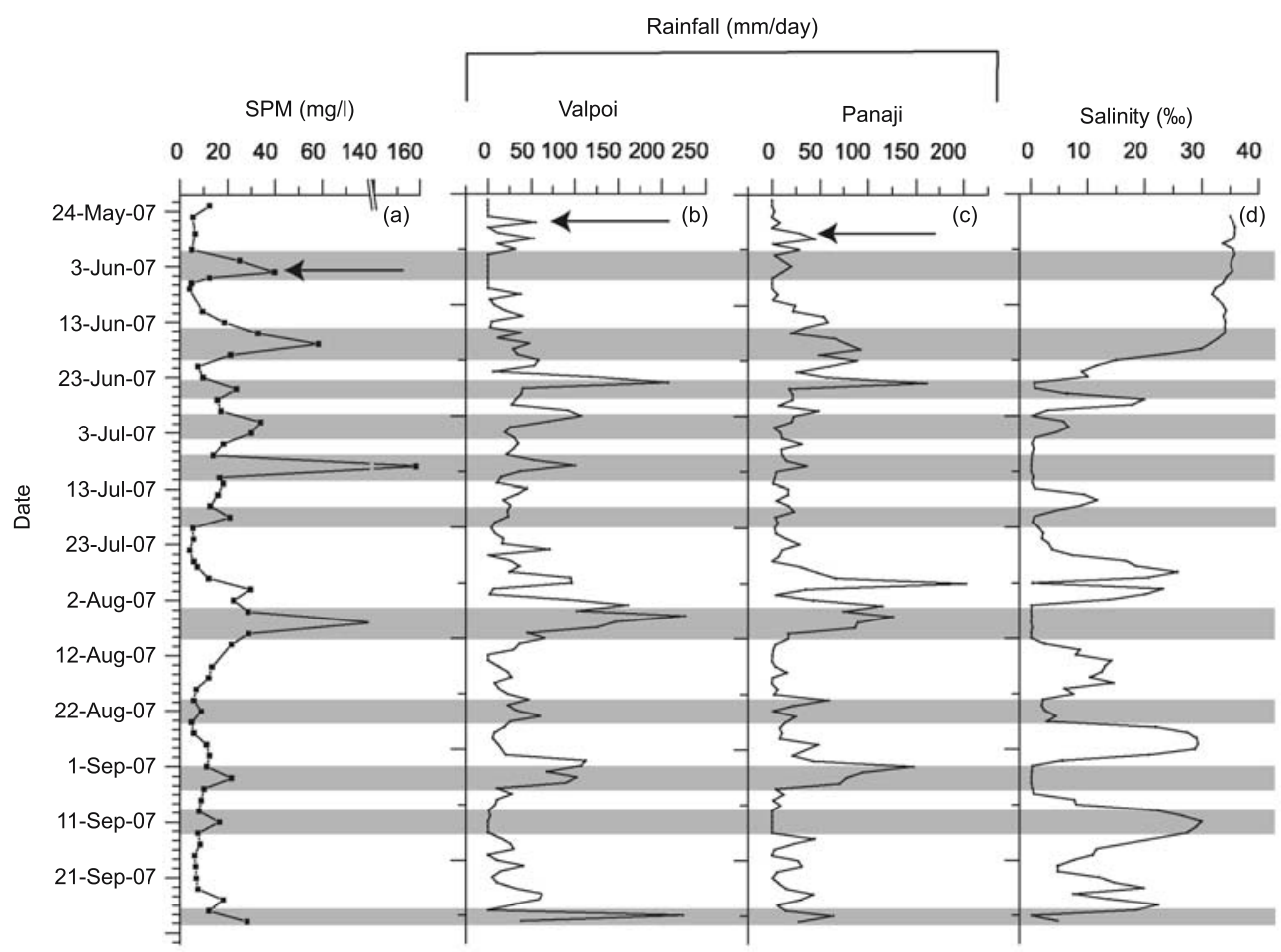

Figure 2. Distribution of (a) suspended particulate matter (SPM) and salinity of the surface waters (d) at regular station in different months. Rainfall data collected at two raingauge stations $(\mathbf{b}-\mathbf{c})$ is also plotted.

active spells of high rainfall. The peaks of moderate SPM concentrations sometimes do not correspond with that of rainfall. The coefficient of correlation $(r)$ between SPM concentrations and rainfall is higher at Valpoi (0.5) than at Panaji (0.3) (figure $3 \mathrm{a}-\mathrm{b}$ ). Surface waters maintained salinity of $\sim 32 \%$ until 17 June 2007 despite the onset of SW monsoon in early June. Thereafter salinity values sharply fall to zero during the larger part of the SW monsoon. Saline water incursions are, however, seen at this station during weak spells of rainfall within the monsoon season. SPM concentrations increase from $3.9 \mathrm{mg} / 1$ to $58 \mathrm{mg} / \mathrm{l}$ despite surface waters maintained 29 to $32 \%$ salinity until 17 June. However, the peaks of very high SPM in July and August coincide with very low salinity of the surface water. SPM exhibits poor correlation $(r=0.12)$ with salinity (figure 3c).

\subsubsection{Transect stations}

A gradual increase in the concentrations of SPM from station 5 to station 1 can be seen at several times both in monsoon and non-monsoon months (figure 4). The concentrations of SPM at sea-end stations $(1,2$ and 3$)$ are two to four times greater than at river-end stations (4 and 5), especially in two different periods, during June-September and February-April (figure 4). The SPM decreases gradually at all stations from September and reach the lowest values in November. Thereafter SPM again increases gradually with highest values in February/March. The concentrations of SPM decrease in April and May, but the values are higher than that in November (figure 4). As far as salinity is concerned, the salinity of the surface waters is $0 \%$ (fluvial) or $<2 \%$ at stations 4 and 5 , but varied widely up to $\leq 15 \%$ at stations 1, 2 and 3 during June-September (figure 4). Highest concentrations of SPM do not coincide with the least salinity of the surface waters during this period. Salinity of the surface waters after September increases more aggressively at sea-end stations (1 and 2), reaching salinity of $20-30 \% 0$ by November and, more gradually at river-end stations, reaching salinity of $20-25 \%$ by January and maintained until May. Very high concentrations of SPM in July-August coincide with low salinities. The low SPM concentrations coinciding with high salinities during October-January and, the highest concentrations of SPM with high salinities during February-April can be seen in figure 4.

The wind speed and direction for 24 hours time and SPM concentrations at the regular station on the date of sample collection shown in figure 5 indicates that the wind speed correlates well with that of the concentrations of SPM. The average wind speed calculated for 2, 3, 4 and $5 \mathrm{~h}$ before sampling indicates that the average 

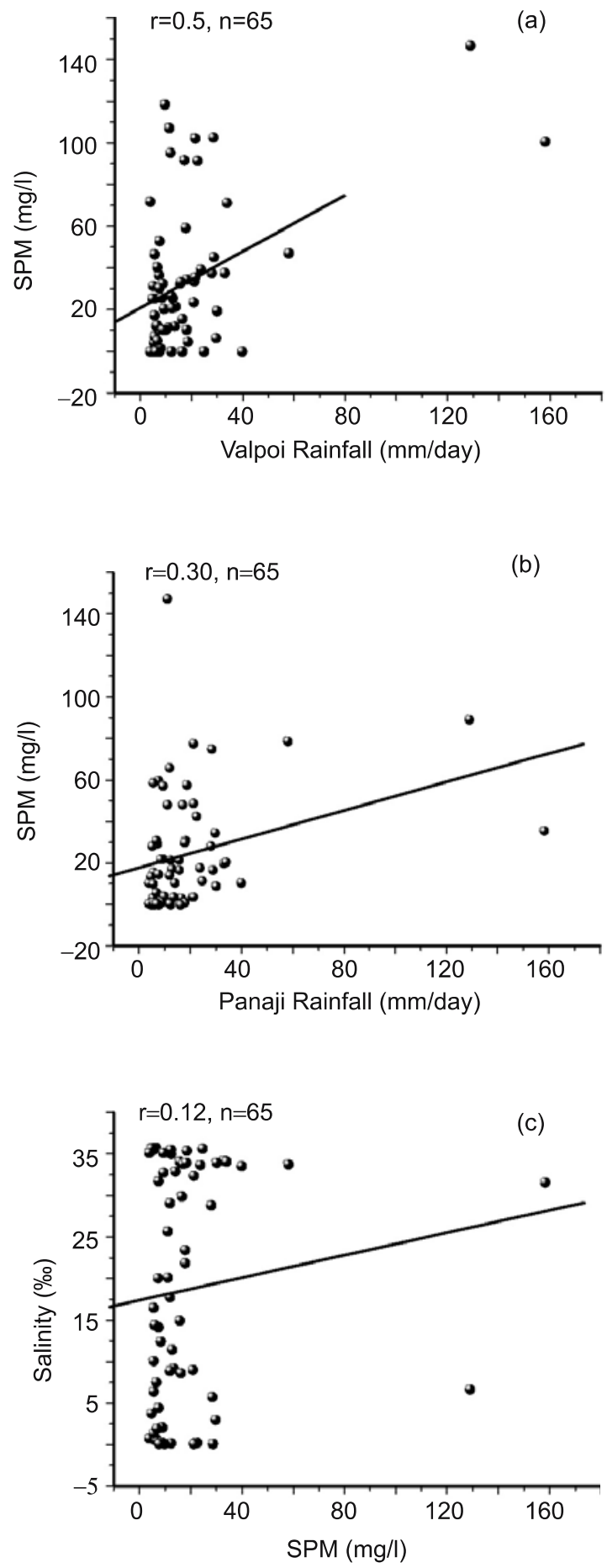

Figure 3. Scatter plots between SPM at regular station vs. rainfall $(\mathbf{a}-\mathbf{b})$ and, SPM vs. salinity at the regular station (c).

speed varies from $5.1-5.7 \mathrm{~ms}^{-1}, \quad 1.8-2.6 \mathrm{~ms}^{-1}$ and $3.2-3.7 \mathrm{~ms}^{-1}$ and $3.4-3.7 \mathrm{~ms}^{-1}$ for JuneSeptember, October-January, February-April and May, respectively. The wind speed exhibits strong correlation with SPM for June-September $(r=0.5$ to 0.98$)$ and February-April $(r=0.81$ to 0.82$)$ and, negative correlation with SPM $(r=-0.65$ to $-0.76)$ for October-January.

\section{Discussion}

\subsection{Relationships among SPM, rainfall and salinity}

Low concentrations of SPM during the premonsoon (May) and its sharp increase during peak monsoon (June-August) indicate the influence of monsoon on total SPM. The peaks of high SPM correspond well with that of high rainfall (figure $2 \mathrm{a}-\mathrm{c}$ ). The low to moderate correlation between SPM and rainfall (figure 3a-b), however, indicate that apart from the suspended matter carried by the river during the monsoon, there may be other sources of SPM, influenced by physicochemical factors. Reworking/resuspension of bottom sediments and biological productivity of the surface waters contribute locally to the total SPM content (Kennedy 1984). The fact that the high SPM of surface waters sharply dropping to $20 \mathrm{mg} / \mathrm{l}$ or less within $48 \mathrm{~h}$ is an indication of involvement of physical, biological and bio-geochemical processes in removing SPM rapidly from the water column. Figure 2 shows considerable variations in day-to-day rainfall and, dry spells of weak rainfall within the monsoon. Moreover, incursion of saline water was observed intermittently at this station even during the monsoon (figure $2 \mathrm{~d}$ ). The regular station thus experienced varied rainfall and salinity conditions, which in turn influenced faster removal of SPM from the surface waters. The time lag between rainfall and SPM (see arrows in figure $2 \mathrm{a}-\mathrm{c}$ ) at the beginning of the monsoon perhaps the time taken for the estuary to respond locally or, time taken for suspended load to reach the regular station. Despite changes in the concentrations of SPM, salinity changes were minor until 17 June (figure 2d); this indicates that the changes in SPM at the beginning of the monsoon were largely due to the resuspension of bottom sediments, in response to local hydrography associated with physical processes in the estuary (see below).

\subsection{Turbidity maxima and related processes}

The concentrations of suspended matter are usually high at the river-end of the estuary and decrease seaward with increase in salinity. Contrastingly, at two different periods, viz., JuneSeptember and February-April, the concentrations of SPM at sea-end stations are orders of magnitude greater (figure 4) suggesting that this part of the channel represent zone of estuarine turbidity maximum (ETM). Several researchers have reported zones of turbidity maxima and also their nature and importance in a large number of estuaries throughout the world (Schubel 1968; 


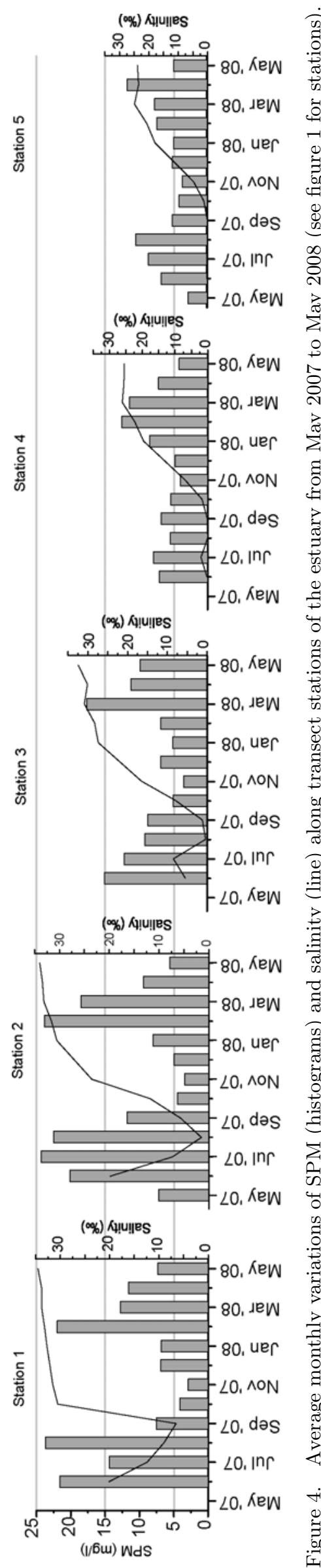

Buller 1975; Festa and Hansen 1978; Allen et al 1980; Schubel and Carter 1984; Nicholas 1986; Officer 1980; Castaing and Allen 1981; Grabermann et al 1997; Sottolichio and Castaing 1999; Chen et al 2005; McManus 2005). The magnitude and location of turbidity maximum is shown to depend upon the settling velocity of the sediment, the amount of sediment introduced at both the ocean and river source and strength of estuarine circulation (Festa and Hansen 1978). Kranck (1984) suggested that the turbidity maxima occur either farther upstream in the source river or farther down stream in the estuary and, forms solely by trapping action of a two-layer estuarine flow. The role of wind in generating turbidity maxima was stressed by Weir and McManus (1987) and Wolanski et al (1995) and, tidal currents by Geyer (1993) and Wellershaus (1981). In the zones turbidity maximum vertical velocities favour accumulation of high SPM. It has been suggested that the flocculants and colloidal substances are highest in this zone and provide major sites for physical, chemical and biological reactions between dissolved and particulate species. This zone acts as a chemical/geochemical filter for removal of dissolved and colloidal species as well as for suspended species (Biggs and Howell 1984).

The ETM occurring in June-September is associated with low salinities and high river discharge. Its formation can be explained by the influence of winds and wind-induced waves and currents and tidal currents associated with the monsoon and river discharge. Strong southwesterly winds with a speed of $5.1-5.6 \mathrm{~ms}^{-1}$ were blowing before $2 \mathrm{~h}$ to $5 \mathrm{~h}$ before sampling and wind speed shows positive correlation ( $r=0.5$ to 0.98$)$ with SPM concentrations during the monsoon. Qasim and Sengupta (1981) and Shetye et al (2007) reported wind speed of $4-7 \mathrm{~ms}^{-1}$, tidal $\left(\sim 2.5 \mathrm{~ms}^{-1}\right.$ high) currents and heavy swells with intensified wave activity during the SW monsoon. Since fresh water discharge is greatest during the SW monsoon there may be an increase in both stratification and strength of the estuarine circulation. The seaward moving dominant surface water river flow counteracts the landward moving bottom flow, intensified winds and wind-induced waves and tidal current activity. The opposing marine and fluviatile processes are sufficiently intense to move sediment up the estuary often causing for the development of turbidity maximum. The magnitude of turbidity maximum has been shown to depend upon both the particle settling velocity and contribution of sediment source from river or oceanic source. The ETM occurring in the fresh water-sea water interface is well known in many estuaries.

Before another ETM that occurred during February-April, the concentrations of SPM 


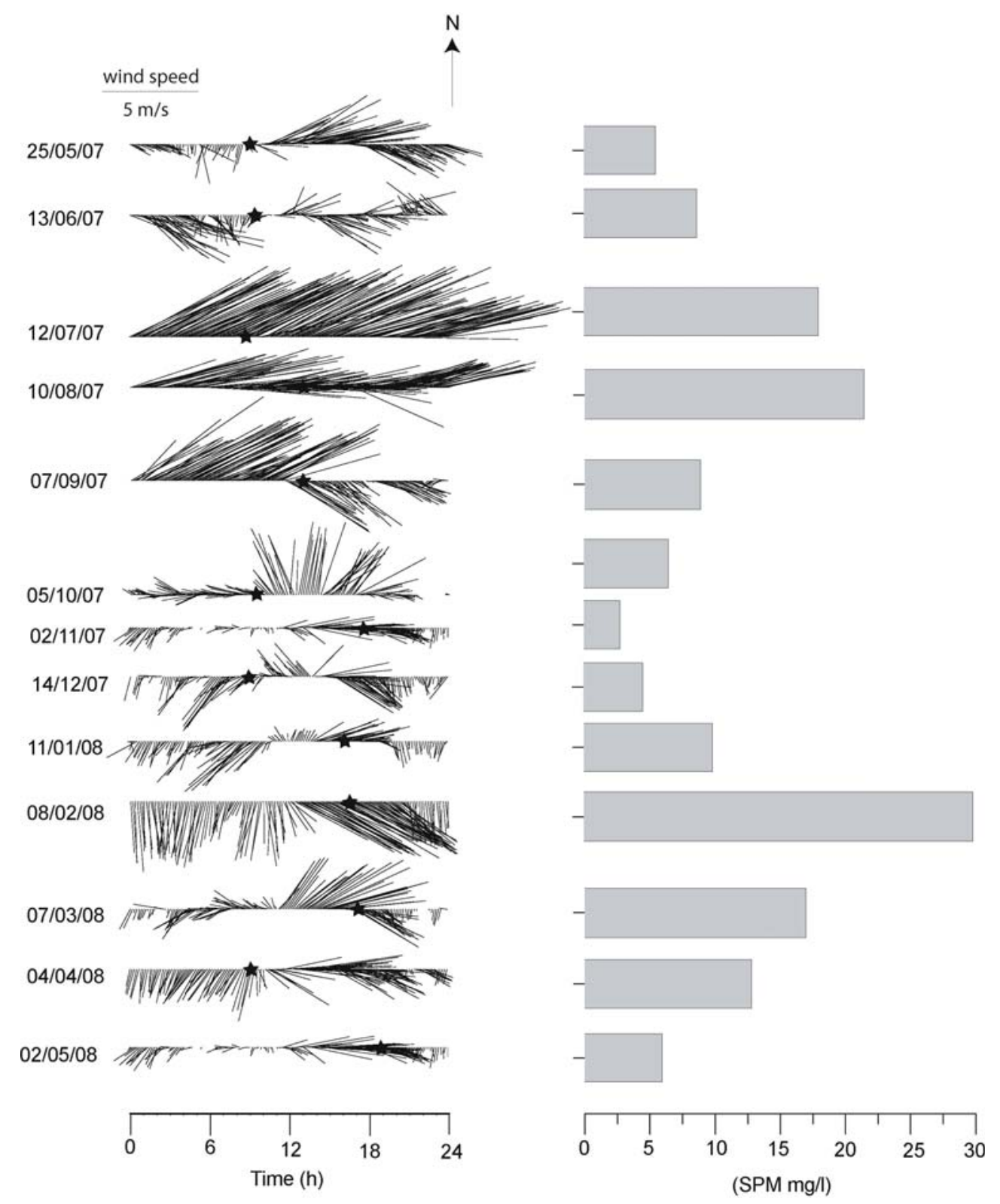

Figure 5. A plot showing concentrations of SPM at the regular station (right) and wind speed and direction in $24 \mathrm{~h}$ (left) on the day of sample collection. Star on the wind plot indicates time of sample collection on that day.

decrease sharply between October and January with the least values in November (figure 4). Though the sediment discharge through river is negligible during October-May, the traffic related to barge movements carrying $\mathrm{Mn}-\mathrm{Fe}$ ores to the offshore and mechanized boats for fishing activity starts at the end of September (immediately after the monsoon) and continued rigorously until May. Therefore one would expect some turbulence related to the propulsion mechanism associated with barges and boats and relatively high SPM concentrations in the estuarine channel. Contrary to the above, the concentrations of SPM decrease and reach lowest in November. Weak easterly winds with speed ranging from 1.8 to $2.6 \mathrm{~ms}^{-1}$ prevailed during October-January (figure 5) and wind speed is negatively correlated $(r=-0.65$ to -0.76$)$ with SPM. Moreover, figure 4 shows intrusion of salt water into the estuarine channel taking place more aggressively at sea-end stations and more gradually at river-end stations. Shetye et al (2007) suggested that the flow in the estuarine channel is primarily tidal in this period and intrusion of salt water takes place gradually several kilometres upstream of the river. Low wind speed probably favoured stratification. It is likely that the salt water intrusion suppressed turbulence and also effectively removed fine-sediment particles in the estuary leading to very low concentrations of SPM in November at all stations. Hamblin (1989) and Geyer (1993) 
demonstrated that the suppression of turbulence by salinity stratification is an important mechanism for trapping of fine-sediment particles during salt water intrusion.

On the other hand, the ETM occurring in February-April coincides with salinities of 20-32\%o at different transect stations (figure 4). Sediment discharge by river is negligible during this period. Therefore this ETM is not simply related to river input of sediment or the one usually reported at fresh water-sea water interface, but resulted from sediment source which is predominantly oceanic or resuspension of bottom sediments. Since the location of ETM is same as the one in JuneSeptember and is of nearly same magnitude, some factors for their formation may be common in both. The wind in these months is dominated by sea breeze. The NW and SW winds blow at a speed of $3.2-3.7 \mathrm{~ms}^{-1}$, stronger wind speed coincides with higher concentrations of SPM (figure 5) and positive correlation $(r=0.81$ to 0.82$)$ exists between the two. Similarly, we found that the tides of 0.4-1.6 $\mathrm{m}$ high are operating in the estuary (tide gauge station is close to regular station) during this period and, strong negative correlation $(r=-0.6)$ exist between the height of the tide and concentrations of SPM. It thus appears that low tides and stronger sea breeze and wind-induced waves have impacted effectively near the mouth of the estuary, causing sediments to resuspend from the bottom or transporting oceanic sediments to the estuary. Neetu et al (2006) studied the wave field exited by sea breeze in shallow areas near the coast off Goa during April and suggested that sea breeze will have significant impact on the coastal processes. Weir and McManus (1987) reported resuspension of bottom sediments at the wind speeds of only $3 \mathrm{~ms}^{-1}$ for $6 \mathrm{~h}$ period in the Tay Estuary. Pattiaratchi et al (2007) and Masselink and Pattiaratchi (1998) suggested that the sea breeze induce pronounced changes to the near shore morpho-dynamics and sediment resuspension in the coastal regions of southwestern Australia. They reported that the incident wave energy increased during sea breeze and was associated with the development of windwave field with significant wave height up to $0.9 \mathrm{~m}$. Sediment suspension was almost continuous and suspended matter increased 6-fold during sea breeze. Wolanski et al (1995) suggested wind is important in wave-driven fluidization of the bed. The erosion rate varies with the sixth power of wave velocity. The powerful sea breeze fronts triggered even thunderstorms in Florida and Gulf of Mexico. We therefore suggest that the ETM during February-April is caused by sea breeze. Since the magnitude of ETM is same that of ETM formed during monsoon the importance of wind, especially sea breeze can not be underestimated.

\section{Acknowledgements}

We thank Dr S R Shetye, the Director and Dr M Dileep Kumar, National Institute of Oceanography (NIO), Goa for their keen interest in the Mandovi Monsoon Experiment 2007 and for providing facilities. We thank Mr M T Babu for providing current data. Dr Aparna Gandhi helped us with wind data and discussion. This is NIO contribution 4532 .

\section{References}

Allen G P, Salmon J C, Bassaullet P, Du Penhoat Y and De Grand P 1980 Effects of tides on mixing and suspended sediment transport in macrotidal estuaries; Sedim. Geol. 26 69-90.

Biggs R B and Howell A A 1984 The estuary as a sediment trap: Alternate approaches to estimating its filtering efficiency; In: The estuary as a filter (ed.) Kennedy V S (New York: Academic Press) p. 107-130.

Buller A T 1975 Sediments of the Tay estuary II formation of ephermal zones of high suspended sediment concentration; Proc. Royal Soc. Edinburgh 75B 65-89.

Castaing P and Allen G P 1981 Mechanisms of seaward escape of suspended sediment from the Gironde: A macrotidal estuary in France; Mar. Geol. 40 101-118.

Chen M S, Wartel S, Eck B V and Maldegam D V 2005 Suspended matter in the Scheldt estuary; Hydrobiol. 540 79-104.

Dyer K R 1986 Coastal and estuarine sediment dynamics (New York: John Wiley) $342 \mathrm{p}$.

Festa J A and Hansen D V 1978 Turbidity maxima in partially mixed estuaries: A two dimensional numerical model; Estuar. Coast. Mar. Sci. 7 347-359.

Geyer W R 1993 The importance of suppression of turbulence by stratification on the estuarine turbidity maximum; Estuaries 16 113-125.

Grabermann I, Uncles R J, Krause G and Stephens J A 1997 Behaviour of turbidity maxima in the Tamar (UK) and Weser (FRG) estuaries; Estuar. Coast. Mar. Sci. $\mathbf{4 5}$ $235-246$

Hamblin P F 1989 Observations and model sediment transport near the turbidity maximum of the Upper Saint Lawrence Estuary; J. Geophys. Res. 94 14,419-14,428.

Kennedy V S 1984 The estuary as a filter (Orlando: Academic Press) 511 p.

Kirby R and Parker W R 1983 Distribution and behavior of fine sediment in the Severn estuary and inner Bristol Channel, UK; Canadian J. Fish. Aqua. Sci. 40 83-95.

Kranck K 1984 The role of flocculation in the filtering of particulate matter in estuaries; In: The estuary as a filter (ed.) Kennedy V S (New York: Academic Press) p. $159-178$.

Le Bris and Glemarec M 1996 Marine and brackish ecosystems of south Brittany (Lorient and Vilaine Bays) with particular reference to the effect of the turbidity maxima; Estuar. Coast. Mar. Sci. 42 737-753.

Masselink G and Pattiaratchi C B 1998 The effects of sea breeze on beach morphology, surf zone hydrodynamics and sediment resuspension; Mar. Geol. 146 $115-135$. 
McManus J 2005 Salinity and suspended matter variations in the Tay estuary; Cont. Shelf Res. 25 729-747.

Nicholas M M 1986 Effects of sediment resuspension in estuaries, In: Estuarine cohesive sediment dynamics (ed.) Mehta A J (New York: Springer) p. 5-42.

Neetu S, Shetye S R and Chandramohan P 2006 Impact of sea breeze on wind-seas off Goa, west coast of India; J. Earth Syst. Sci. 115 229-234.

North E W, Hood R R, Chao S Y and Sanford L P 2005 The influence of episodic events on transport of Striped Bass eggs to the estuarine turbidity maximum nursery area; Estuaries 28 108-123.

Officer C B 1980 Discussion of the turbidity maximum in partially mixed estuaries; Estuar. Coast. Mar. Sci. 10 239-246.

Pattiaratchi C B, Hegge B, Gould J and Eliot I 1997 Impact of sea-breeze activity on nearshore and foreshore processes in southwestern Australia; Cont. Shelf Res. 17 $1539-1560$.

Qasim S Z and Sengupta R 1981 Environmental characteristics of the Mandovi-Zuari estuarine system in Goa; Estuar. Coast. Mar. Sci. 13 557-578.

Schubel J R 1968 Turbidity maxima of the northern Chesapeake Bay; Science 161 1013-1015.

Schubel J R and Carter H H 1984 The estuary as a filter for fine-grained suspended sediment; In: The estuary as a filter (ed.) Kennedy V S (New York: Academic Press) p. $81-106$.

Schubel J R and Kennedy V S 1984 The estuary as a filter: An introduction, In: The estuary as a filter (ed.) Kennedy V S (New York: Academic Press) p. 1-14.

Schoellhamer D H 2001 Influence of salinity, bottom topography, and tides on locations of estuarine turbidity maxima in northern San Francisco Bay; In: Coastal and Estuarine fine sediment transport processes (eds) McAnally W $\mathrm{H}$ and Mehta A J, Elsevier Science B.V. 343-357.

Shetye S R, Gouveia A D, Singbal S Y S, Naik C G, Sundar D, Michael G S and Nampoorthiri G 1995 Propagation of tides in the Mandovi-Zuari estuarine network; Proc. Indian Acad. Sci. (Earth and Planet. Sci.) 104 667-682.

Shetye S R, Kumar M D and Shankar D 2007 The Mandovi and Zuari estuaries; National Institute of Oceanography, Goa, $145 \mathrm{p}$.

Sottolichio A and Castaing P 1999 A systhesis on seasonal dynamics of highly-concentrated structures in the Gironde estuary; C.R. Acad. Sci., Paris, Sciences de la terre et des planetes 329 795-800.

Sundar D and Shetye S R 2005 Tides in the Mandovi and Zuari estuaries, Goa, west coast of India; J. Earth Syst. Sci. 114 493-503.

Uncles R J, Barton M L and Stephens J A 1994 Seasonal variability of fine-sediment concentrations in the turbidity maximum region of the Tamar estuary; Estuar. Coast. Shelf Sci. 38 19-39.

Weir D J and McManus J 1987 The role of wind in generating turbidity maxima in the Tay estuary; Cont. Shelf Res. 7 1315-1318.

Wellershaus S 1981 Turbidity maximum and mud shoaling in the Weser Estuary; Archive Hydrobiol. 92 161-198.

Wolanski E, King B and Galloway D 1995 Dynamics of the turbidity maximum in the Fly River Estuary, Papua New Guinea; Estuar. Coast. Shelf Sci. 40 321-337. 